${ }^{1}$ Wydział Medyczny, Warszawski Uniwersytet Medyczny

${ }^{2}$ Kolegium Nauk Medycznych, Uniwersytet Rzeszowski

\title{
WPEYW PANDEMII KORONAWIRUSA NA CZĘSTOŚĆ WYSTĘPOWANIA I NASILENIE DOLEGLIWOŚCI CZĘŚCI SZYJNEJ KRĘGOSEUPA W GRUPIE PRACOWNIKOW BIUROWYCH PRZENIESIONYCH DO PRACY ZDALNEJ
}

The impact of the coronavirus pandemic on the incidence and severity of neck pain in office workers shifted to home office.

\section{Słowa kluczowe:}

praca zdalna, kręgosłup szyjny, bóle kręgosłupa, koronawirus, pandemia.

\section{Key words:}

home office, cervical spine, neck pain, coronavirus, pandemic.

\section{Streszczenie}

Wstęp.

Globalna pandemia koronawirusa spowodowała rosnacy trend w kierunku przechodzenia pracowników na pracę zdalną.

Cel.

Ocena wplywu pracy zdalnej na dolegliwości bólowe części szyjnego kręgosłupa u pracowników administracyjnobiurowych.
Badana grupa i metoda badań.

W badaniu posłużono się ankietą internetową Computer-Assisted Web Interviewing (CAWI). W grupie 103 respondentów, 55 kobiet i 48 mężczyzn w wieku od 24 do 52 lat udzieliło odpowiedzi na pytania ułożone w 14 sekcjach, dostarczając informacji na temat stylu życia, aktywności fizycznej, warunków i ergonomii pracy biurowej oraz zdalnej, pytań bazujących na kwestionariuszu Neck Disability Index (NDI) w zakresie oceny dolegliwości odcinka szyjnego kręgosłupa.

Wyniki.

Wydaje się, że przejście na pracę zdalną wiąże się ze zwiększonym ryzykiem doświadczenia dolegliwości bólowych szyi. Nie obserwowaliśmy tego w naszej pracy. W naszych badaniach mniejszy procent pracowników biurowych zgłaszał dolegliwości, dodatkowo też o mniejszym nasileniu. Wydaje się również, że ilość codziennej aktywności fizycznej podejmowanej przez pracownika ma znaczenie w kontekście prewencji wystąpienia dolegliwości, lecz ani spadek ilości aktywności ani wzrost po przejściu na prace zdalną nie wpłynęly znacząco na odczuwane dolegliwości u pracowników. Warunki ergonomii korelują ujemnie z częstością zgłaszanych dolegliwości.

Wnioski.

Telepraca może zmniejszyć bóle szyi. Większa aktywność fizyczna wiąże się z mniejszą ilością bólów szyi w badanej grupie.

\section{Summary}

\section{Introduction.}

The global coronavirus pandemic has resulted in a growing trend toward shifting office workers to home office. 


\section{Objective.}

Assessment of the impact of remote work on neck pain in administrative and office workers.

\section{Material and method.}

We used the Computer-Assisted Web Interviewing (CAWI) questionnaire. In the group of 103 respondents, 55 women and 48 men aged 24 to 52 answered the questions in 14 sections, providing information on lifestyle, physical activity, office and remote conditions and ergonomics, questions based on the Neck Disability Index questionnaire ( NDI) in the assessment of the cervical spine.

\section{Results.}

There is a risk of experiencing neck pain when switching to remote work. However, in this study, a decrease in the frequency of symptoms and their severity was observed after switching to remote work. The amount of physical activity undertaken by an employee is important in the context of preventing the occurrence of ailments, but neither its decrease nor its increase after switching to remote work significantly influenced the experienced ailments in employees. Ergonomic conditions negatively correlate with the frequency of reported ailments.

\section{Conclusions.}

Shifting to remote home office may reduce neck pain. More physically active workers experience less often and less severe neck pain.

\section{Wstęp}

Ból szyi znajduje się na 4 miejscu z 291 dolegliwości ograniczających sprawność pacjentów oraz na 21 miejscu jako czynnik obniżający jakość życia. Szacuje się, że około połowa wszystkich ludzi doświadczy w ciągu swojego życia przynajmniej jednego istotnego klinicznie epizodu bólu odcinka szyjnego kręgosłupa, u 54\% osób istnieje ryzyko wystąpienia dolegliwości w ciągu najbliższych 6 miesięcy, a chorobowość punktowa (tj. w danym dniu) dla bólu szyi waha się między 6-22\% w zależności od regionu geograficznego, definicji bólu szyi i sposobu przeprowadzania badań $[1,2,3,4]$.

W związku z rozpowszechnieniem się dystansu społecznego jako skutecznego narzędzia zapobiegającego rozprzestrzenianiu się COVID-19, chorobie spowodowanej pandemia koronawirusa SARS-CoV-2, sytuacja w biurach wielu firm ulega drastycznym przemianom. Koszty zdrowotne i finansowe utrzymania pracowników firm na biurowych stanowiskach niejednokrotnie mogłyby przewyższać realne korzyści płynące z trzymania pracownika $\mathrm{w}$ miejscu pracy w niebezpiecznym dla zdrowia okresie. Z każdym miesiącem od początku pandemii przybywa firm, które decyduja się na przejście na pracę zdalną częściowo, w całości lub w systemie zmianowym tzn. część pracowników pracuje w biurze, a część zdalnie, po określonym czasie zamieniając się formą realizacji służbowych obowiązków.

W kontekście wciąż nieuregulowanej sytuacji prawnej pracy zdalnej jako stałego rozwiązania w umowie między pracownikiem i pracodawca, jest to rozwiązanie o niewiadomym wpływie na zdrowie fizyczne i psychiczne pracowników $[5,6,7]$.

Praca biurowa jest obecnie bardzo popularną formą wykonywania służbowych obowiązków. Szacuje się, że między $33 \%$ a $44 \%$ osób pracujących zatrudnionych jest na stanowisku biurowym [8]. Powszechnie wiadomo, jak duże zagrożenie niesie ze sobą siedzący tryb życia, którego praca biurowa jest bardzo istotnym prekursorem. Zagrożenia dla odcinka szyjnego kręgosłupa są coraz lepiej poznawane, a praca biurowa jest jednym z czynników ryzyka pojawienia się dolegliwości bólowych w odcinku szyjnym. Wydaje się że w momencie, kiedy pracownik zmienia miejsce pracy z ergonomicznie zaprojektowanego biura na mniej lub bardziej prowizorycznie zorganizowane miejsce pracy $\mathrm{w}$ domu, powstaje szereg dodatkowych niekorzystnych czynników, mogących pogorszyć lub wywołać objawy ze strony odcinka szyjnego kręgosłupa. Wykonywanie obowiązków pracowniczych zdalnie ma też swoje potencjalnie dobre strony. Istnienie fizycznej odległości między pracownikiem a przełożonym oraz nieprzebywanie codziennie $\mathrm{w}$ atmosferze biurowej, może dla niektórych pracowników oznaczać sporą redukcję odczuwanego stresu. Praca zdalna stwarza też możliwości swobodnego podejścia do nieregulowanych przerw $\mathrm{w}$ pracy. Tak zwany zadaniowy czas pracy może w praktyce oznaczać dowolność dla pracownika w kwestii ilości, długości i formy, w jakiej spędza czas przerw od pracy. Przejście na pracę biurową może być też okazją do zwiększenia codziennej aktywności fizycznej, która wpływa prewencyjnie na wiele dolegliwości narządu ruchu człowieka. W wyniku pandemii wielu pracodawców pozwoliło na realizację części zadań zawodowych z domu lub też całkowicie zrezygnowało $\mathrm{z}$ tradycyjnej formy pracy biurowej w miejscu zatrudnienia. Pojawiły się także doniesienia o firmach, które planują przyjęcie rozwiązań pracy zdalnej na stałe, co według niektórych doniesień koresponduje $\mathrm{z}$ oczekiwaniami ze strony pracowników [1,6,9,10,11,12,13].

\section{Cel pracy}

Celem pracy było zweryfikowanie, czy przejście na pracę zdalną niesie ze sobą konsekwencje zdrowotne w postaci zwiększenia częstości występowania i nasilenia bólów kręgosłupa szyjnego. Postawiono następujące pytania badawcze: 


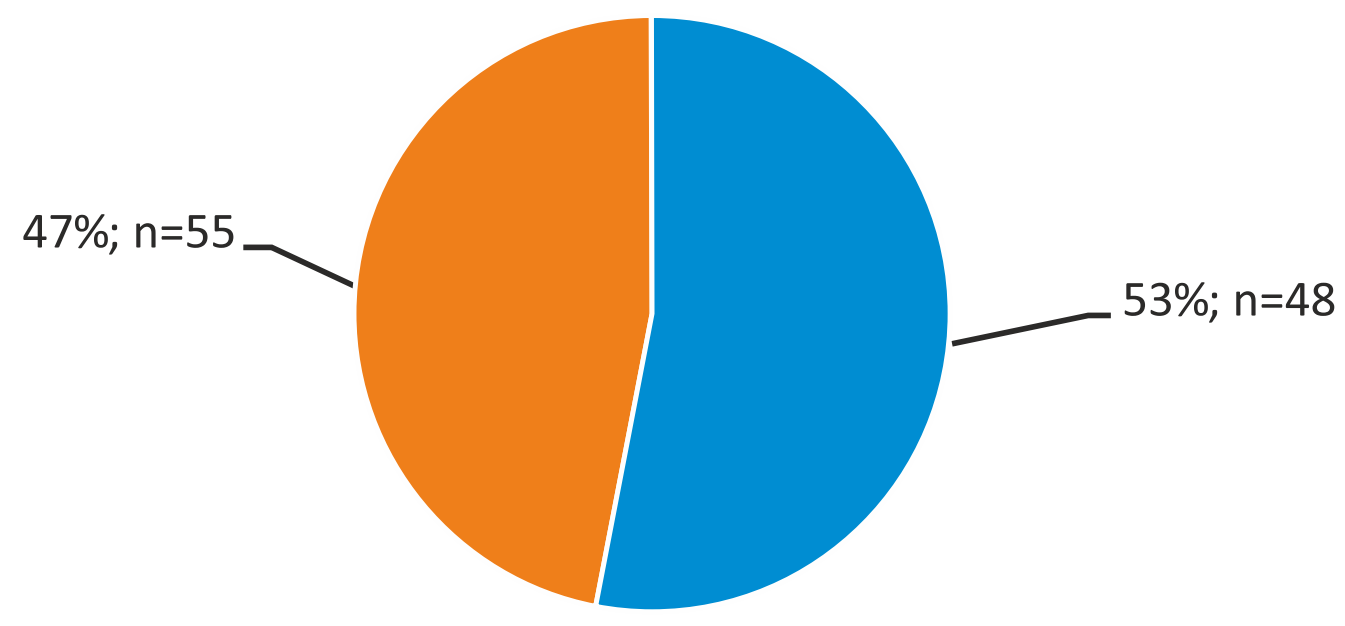

Kobiety Mężczyźni

Ryc. 1. Płeć ankietowanych (n=103) [źródło: opracowanie własne]

\section{$\%$ badanych}

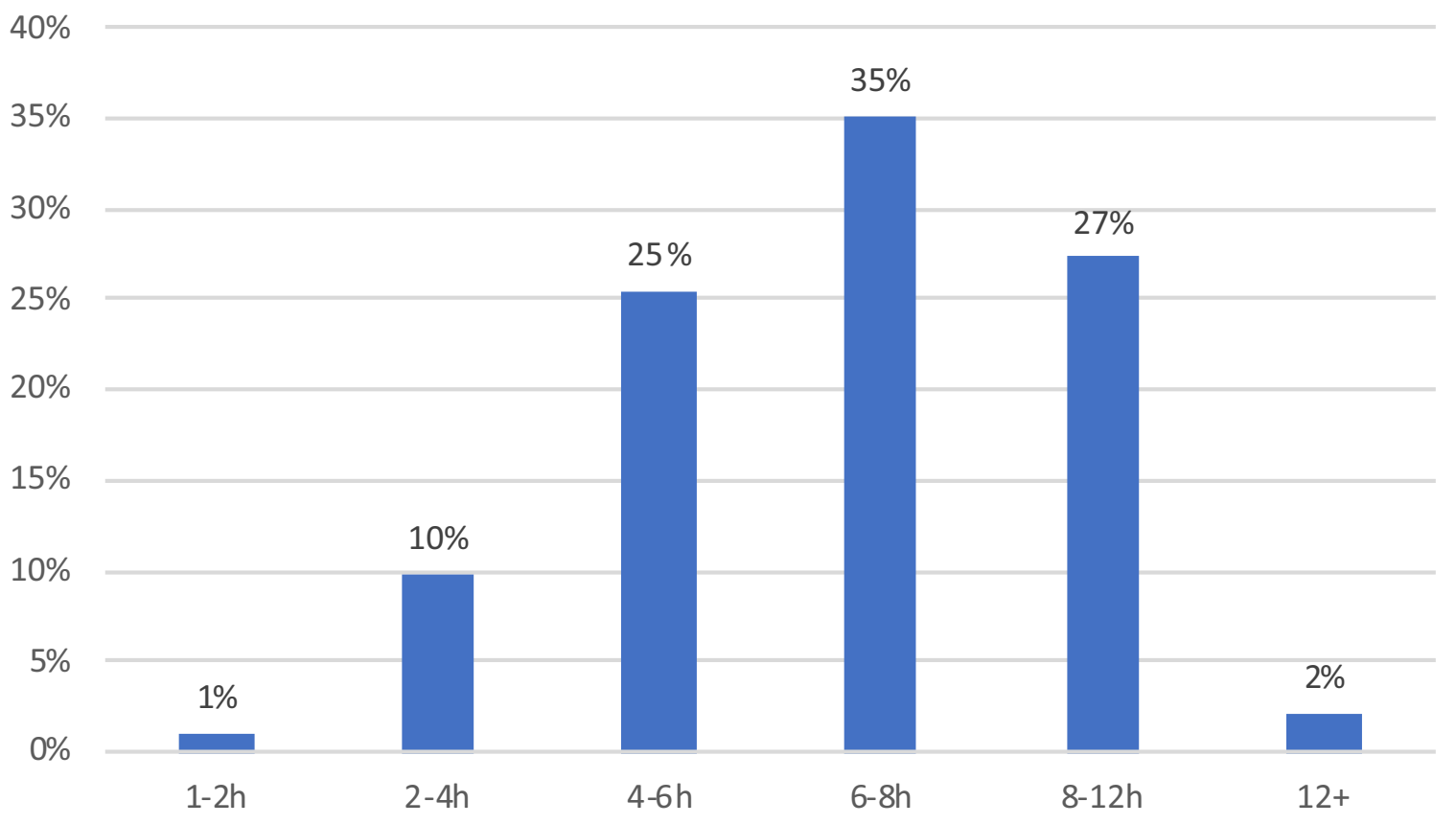

Czas pracy siedzącej w ciągu dnia

Ryc. 2. Czas pracy siedzącej w ciągu dnia deklarowana przez badanych ( $n=103$ ) [źródło: opracowanie własne]

- Czy praca zdalna niesie ze sobą ryzyko wystąpienia dolegliwości ze strony odcinka szyjnego kręgosłupa?

- Czy u osób pracujących biurowo z objawami ze strony odcinka szyjnego kręgosłupa, przejście na pracę zdalną przyniosło poprawę czy pogorszenie stanu zdrowia?

- Czy ergonomia miejsca pracy (biuro lub dom) ma związek z odczuwanymi objawami ze strony odcinka szyjnego kręgosłupa?

- Czy przejście na pracę zdalną wiąże się ze zmianą częstości podejmowanej aktywności fizycznej i czy ta zmiana 


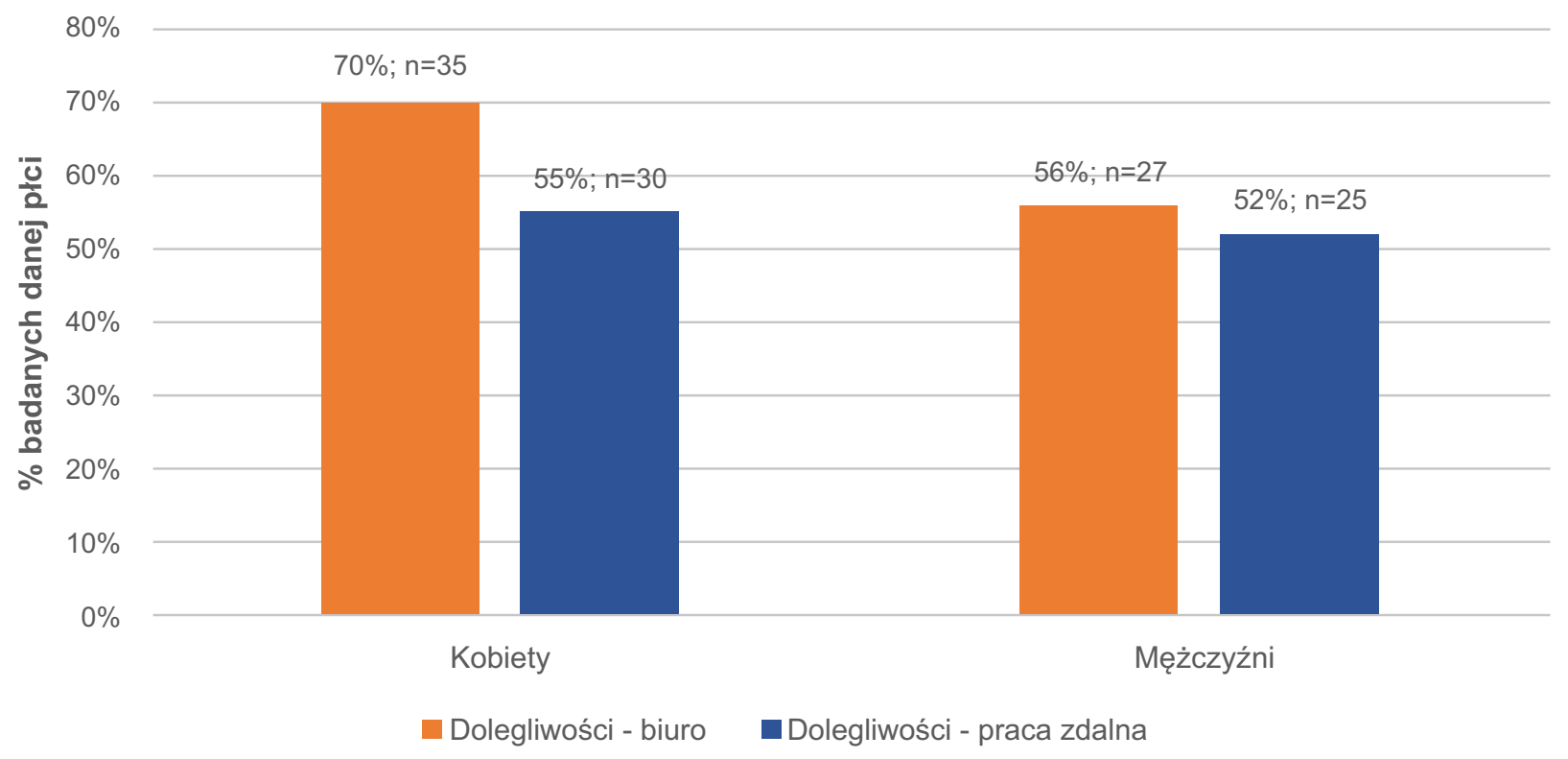

Ryc. 3. Występowanie dolegliwości kręgosłupa szyjnego podczas pracy w biurze i w trakcie pracy zdalnej w zależności od płci (n=103) [źródło: opracowanie własne]

Ograniczenie zakresu ruchu

Uczucie sztywności

Mrowienie/zaburzenia czucia w kończynach górnych

Kręcz szyi / "postrzał" / nagły wzrost napięcia mięśni w obrębie szyi/ramion/łopatki

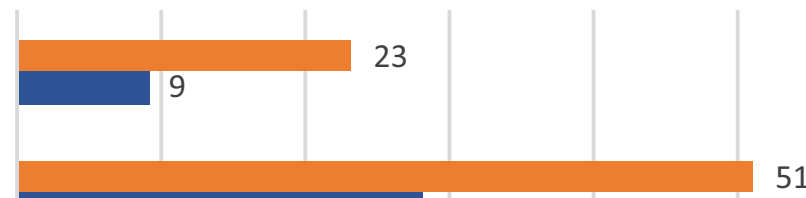

Bóle głowy

Ból szyi

Ból karku

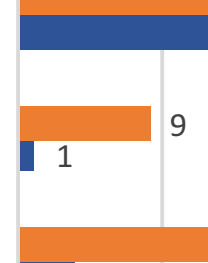

28

51

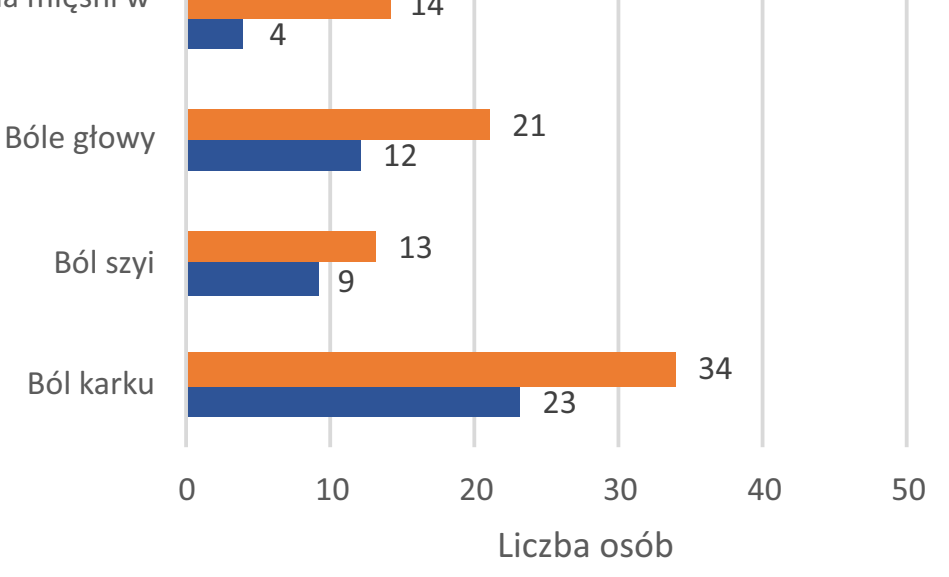

Obserwowane w trakcie pracy biurowej Obserwowane w trakcie pracy zdalnej

Ryc. 4. Rodzaj odczuwanych dolegliwości w pracy biurowej i zdalnej ( $n=103$ ) [źródło: opracowanie własne]

www.kif.info.pl 
\% osób badanych

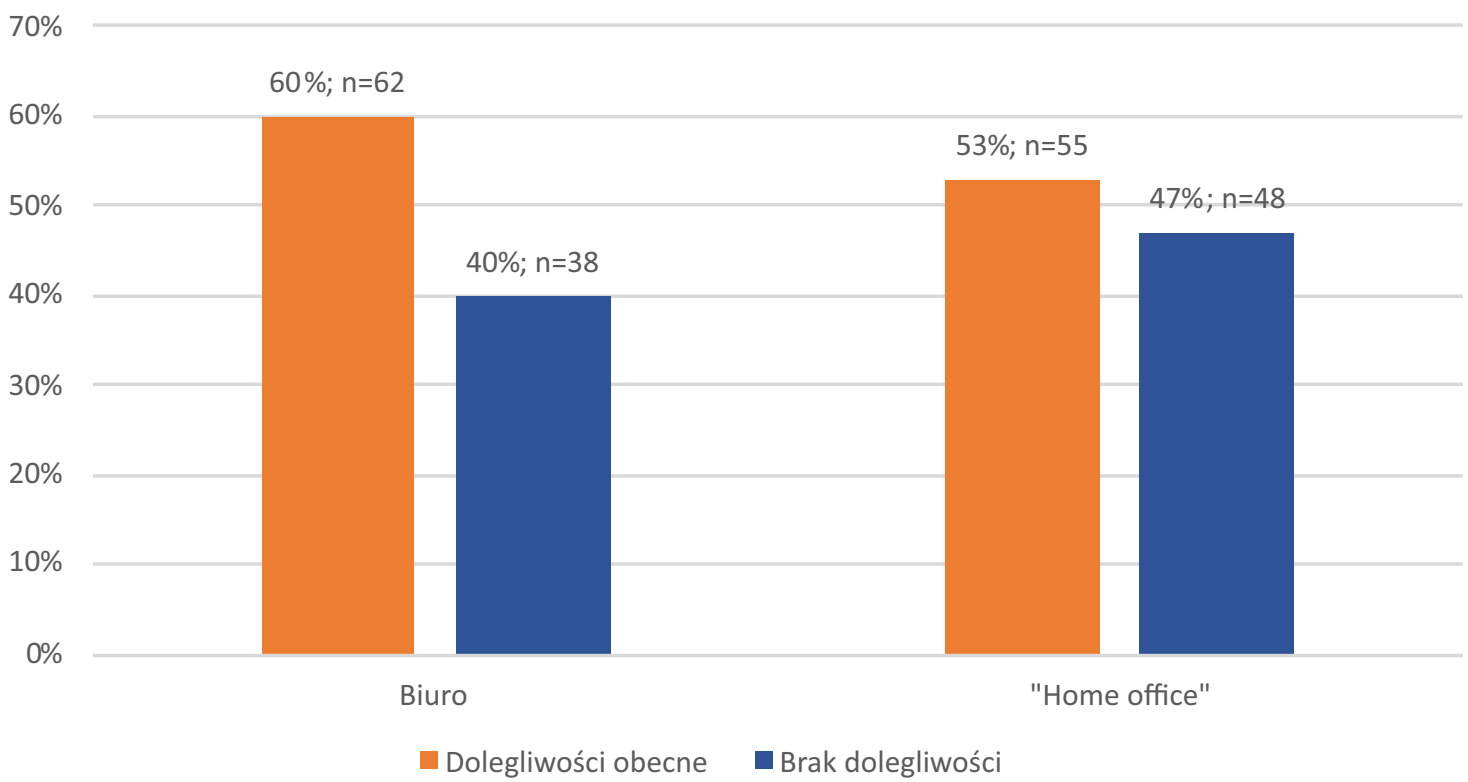

Ryc. 5. Tryb pracy a występowanie dolegliwości bólowych kręgosłupa szyjnego (n=103) [źródło: opracowanie własne]

Wpływ na rekreację

Wpływ na sen

Wpływ na jazdę samochodem

Wpływ na pracę

Wpływ na zdolność do koncentracji

Wpływ na ból głowy

Wpływ na czytanie

Wpływ na podnoszenie przedmiotów

Wpływ na codzienne czynności

Nasilenie dolegliwości
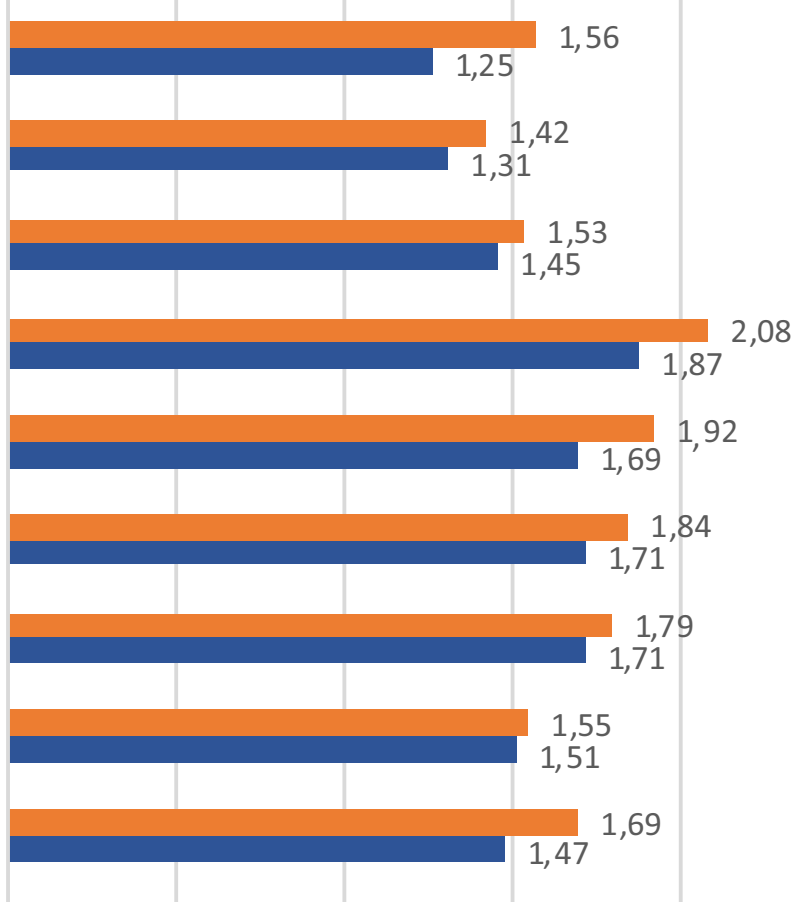

2,51

0,00

0,50

1,00

1,50

2,00

2,50

3,00

3,50

- Biuro Home Office

Ryc. 6. Średni poziom parametrów NDI (bóle kręgosłupa szyjnego) podczas pracy w biurze i pracy zdalnej (n=103) [źródło: opracowanie własne] 
$\%$ badanych

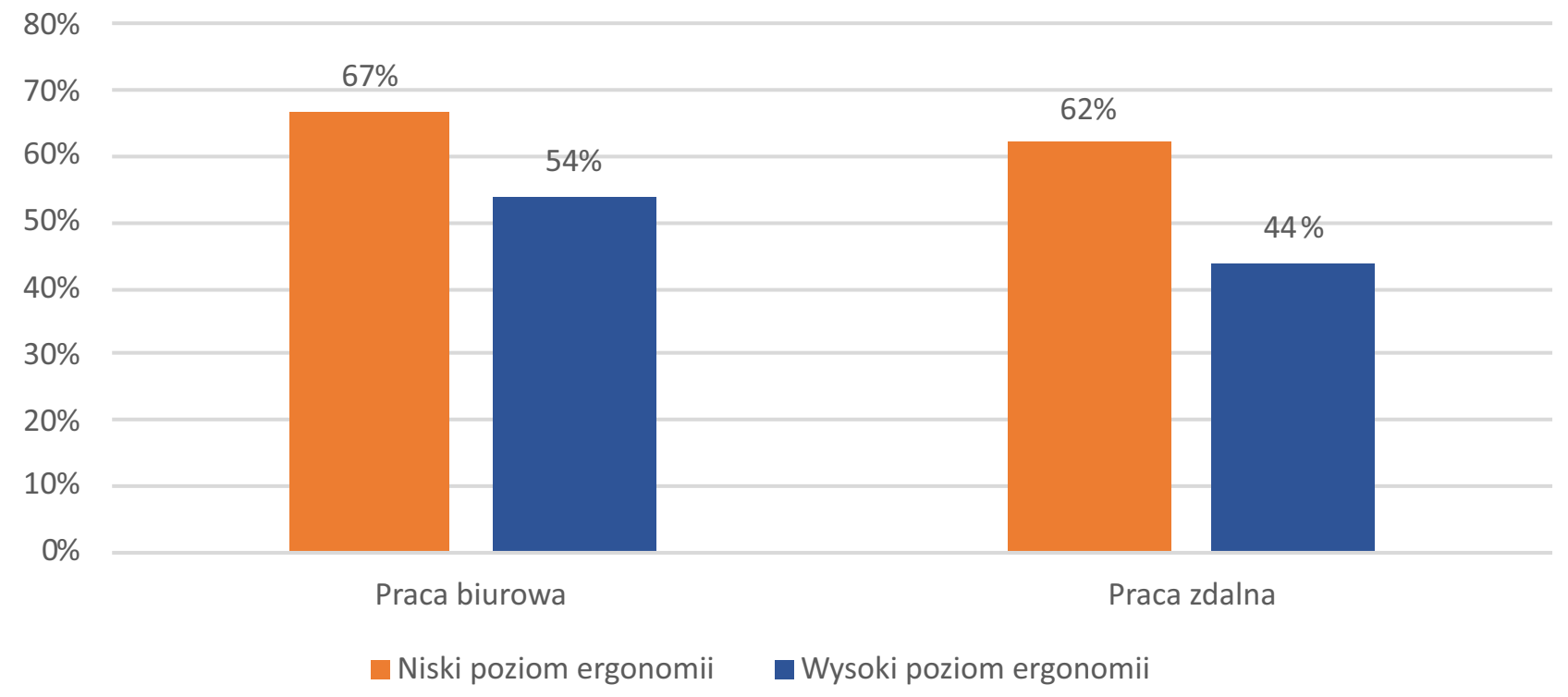

Ryc. 7. Wpływ poziomu ergonomii na częstość występowania dolegliwości ze strony szyi [źródło: opracowanie własne]

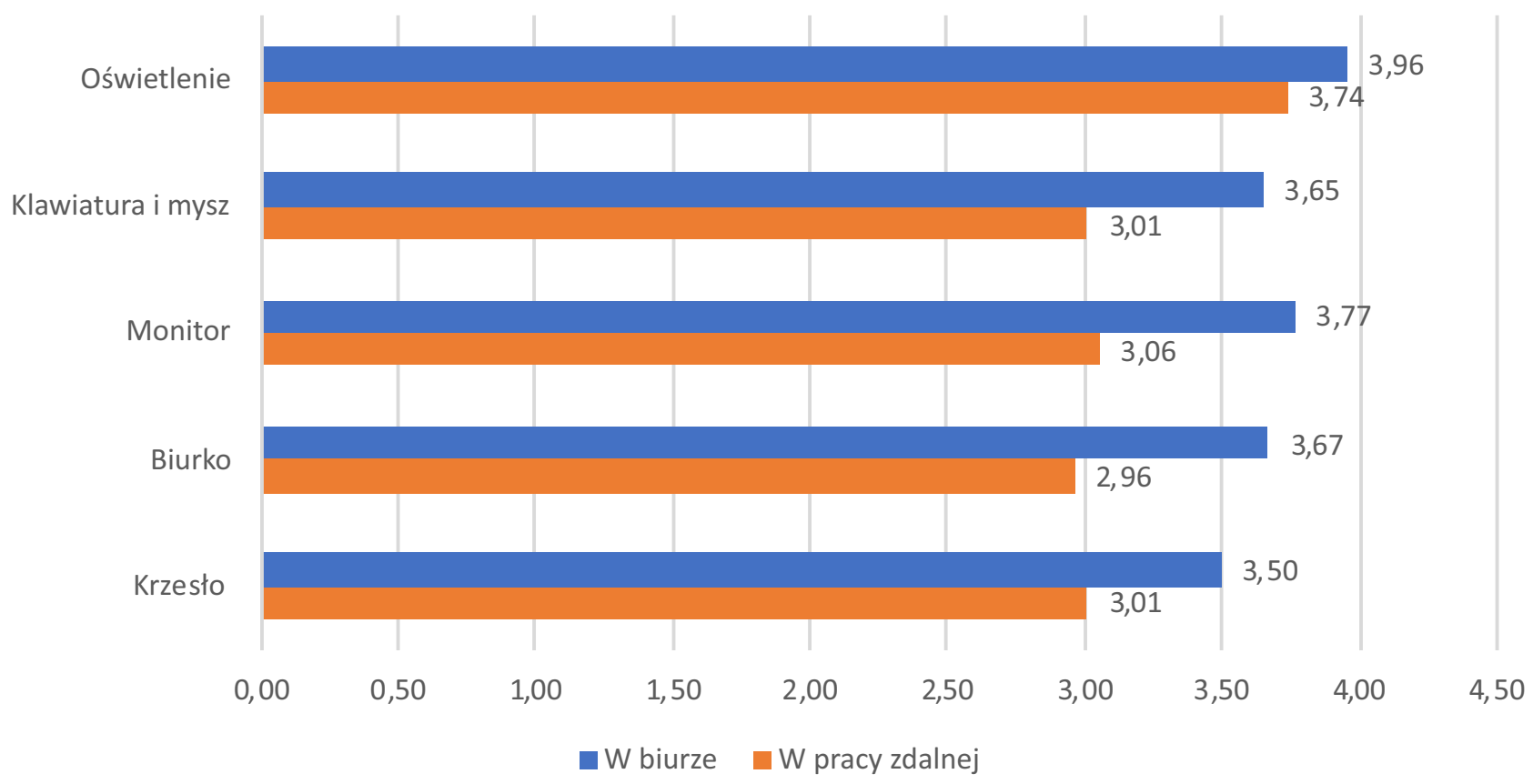

Ryc. 8. Ocena poziomu ergonomii poszczególnych elementów miejsca pracy [źródło: opracowanie własne]

www.kif.info.pl 
\% badanych zgłaszających dolegliwości

$80 \%$

$70 \%$

$60 \%$

$54 \%, n=37$

$50 \%$

$40 \%$

$30 \%$

$20 \%$

$10 \%$

$0 \%$

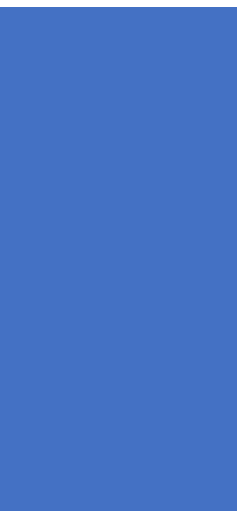

Biura z miejscem do odpoczynku

$71 \%, n=25$

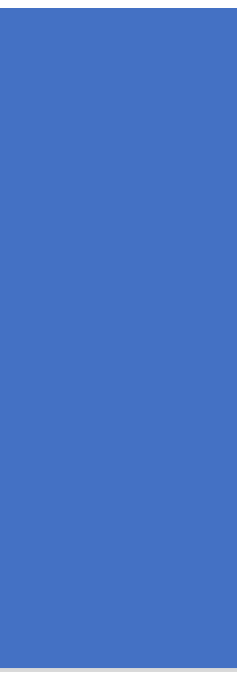

Biura bez przestrzeni do odpoczynku

Ryc. 9. Wpływ obecności miejsca do wypoczynku w pracy na częstotliwość występowania dolegliwości [źródło: opracowanie własne]

Aktywność fizyczna >5h / tydz.

Aktywność fizyczna 2,5-5h / tydz.

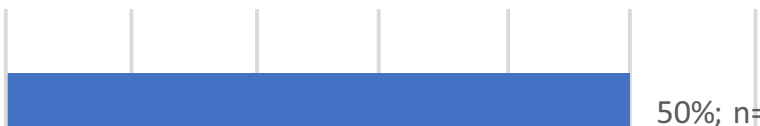

Aktywność fizyczna $<2,5 \mathrm{~h} / \mathrm{tydz}$.

Brak aktywności fizycznej

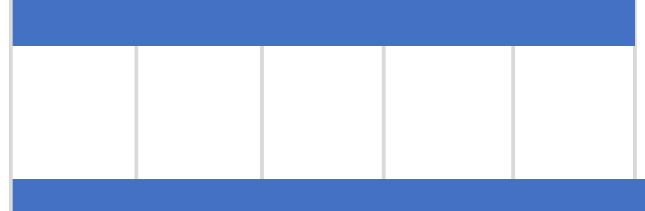

0\%; $n=8$

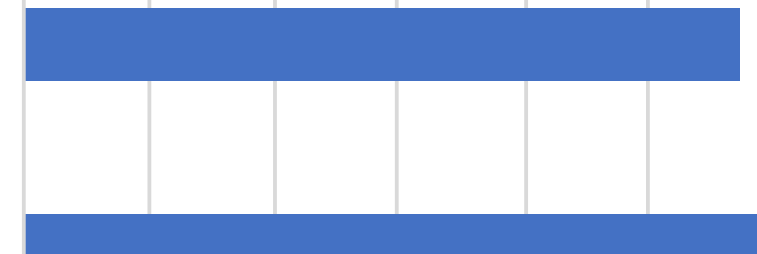

$57 \% ; n=17$

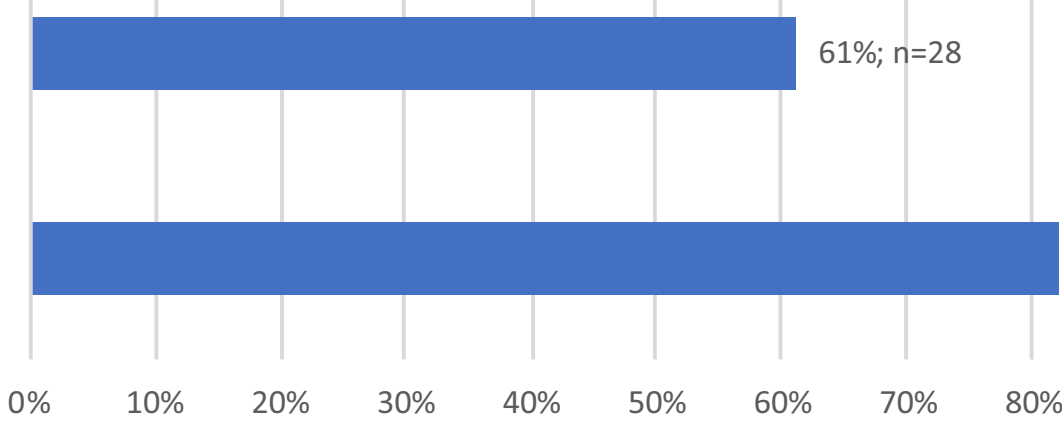

$82 \% ; n=9$

$0 \%$

$80 \%$

$90 \%$

Ryc. 10. Wpływ objętości aktywności fizycznej na częstość występowania dolegliwości [źródło: opracowanie własne] 
ma wpływ na odczuwane dolegliwości ze strony odcinka szyjnego kręgosłupa?

- Czy przebyty w przeszłości uraz kręgosłupa szyjnego może mieć wpływ na dolegliwości bólowe odcinka szyjnego kręgosłupa?

\section{Badana grupa}

W badaniu wzięło udział 103 pracowników biurowych (55 kobiet i 48 mężczyzn) małych i średnich firm, działających na terenie Warszawy i Krakowa. Badaniu, polegającemu na uzupełnieniu anonimowej ankiety on-line, poddano pracowników biurowych, którzy w okresie 10 miesięcy poprzedzających badanie pracowali stacjonarnie w biurze firmy lub wynajętej przestrzeni do pracy wspólnej, a następnie w związku z zaleceniami w okresie pandemii wirusa SARS CoV-2 przeszli na prace zdalną. Kwestionariusz pozostawał otwarty na przyjmowanie odpowiedzi w okresie od sierpnia 2020 r. do września 2020 r.

\section{Metoda badań}

W badaniu wykorzystano ankietę w formie kwestionariusza internetowego
CAWI - Computer-Assisted Web Interviewing, stworzonego $\mathrm{w}$ oparciu o zmodyfikowaną wersję kwestionariusza Neck Disability Index (NDI). Modyfikacja polegała na przeskalowaniu opisywanych przez ankietę dolegliwości na potrzeby populacji bez objawów wymagających leczenia ambulatoryjnego lub szpitalnego. Wykorzystano popularne narzędzie do tworzenia ankiet internetowych Formularze Google (Google Forms). Pozwala ono na stworzenie rozbudowanej ankiety z podziałem na sekcje. Umożliwia wykorzystanie różnych rodzajów pytań, pozwalając na wskazanie w każdej sekcji pytań wymaganych, bez uzupełnienia których niemożliwe jest przejście do następnej sekcji ankiety. Interfejs użytkownika umożliwia podgląd w czasie rzeczywistym napływających odpowiedzi oraz podstawową analizę zebranych informacji. W dowolnym momencie istnieje możliwość pobrania wyników ankiety w formie danych wyeksportowanych do pliku arkuszy kalkulacyjnych, które następnie można poddać obróbce np. w programach MS Office Excel.
Wykreowany kwestionariusz został zatytułowany „Wpływ telepracy (home office) na dolegliwości odcinka szyjnego kręgosłupa u pracowników biurowych". Ankieta składała się z 14 sekcji. Dla lepszego wglądu w sytuację poszczególnych grup pracowników, obliczono Wskaźnik Niepełnosprawności Szyjnej (ang. Neck Disability Index, NDI). Wskaźnik ten powstaje poprzez zsumowanie zeskalowanych numerycznie odpowiedzi respondentów w częściach ankiety powstałych na podstawie zmodyfikowanego kwestionariusza NDI. Odpowiedź określająca najmniejsze dolegliwości oznacza się cyfrą 1, następnie kolejno narastające nasilenie dolegliwości numeruje się cyframi od 2 do 6 . Wskaźnik składa się z 10 pytań, po 6 stopni nasilenia dolegliwości każde. Przedział liczbowy dla wyniku wskaźnika NDI zawiera się między 10 a 60 , gdzie 10 to najniższy stopień niepełnosprawności, a 60 to wysoki stopień niepełnosprawności związany z bólami części szyjnej. W trakcie analizy odpowiedzi stworzono na potrzeby niniejszej pracy wskaźnik

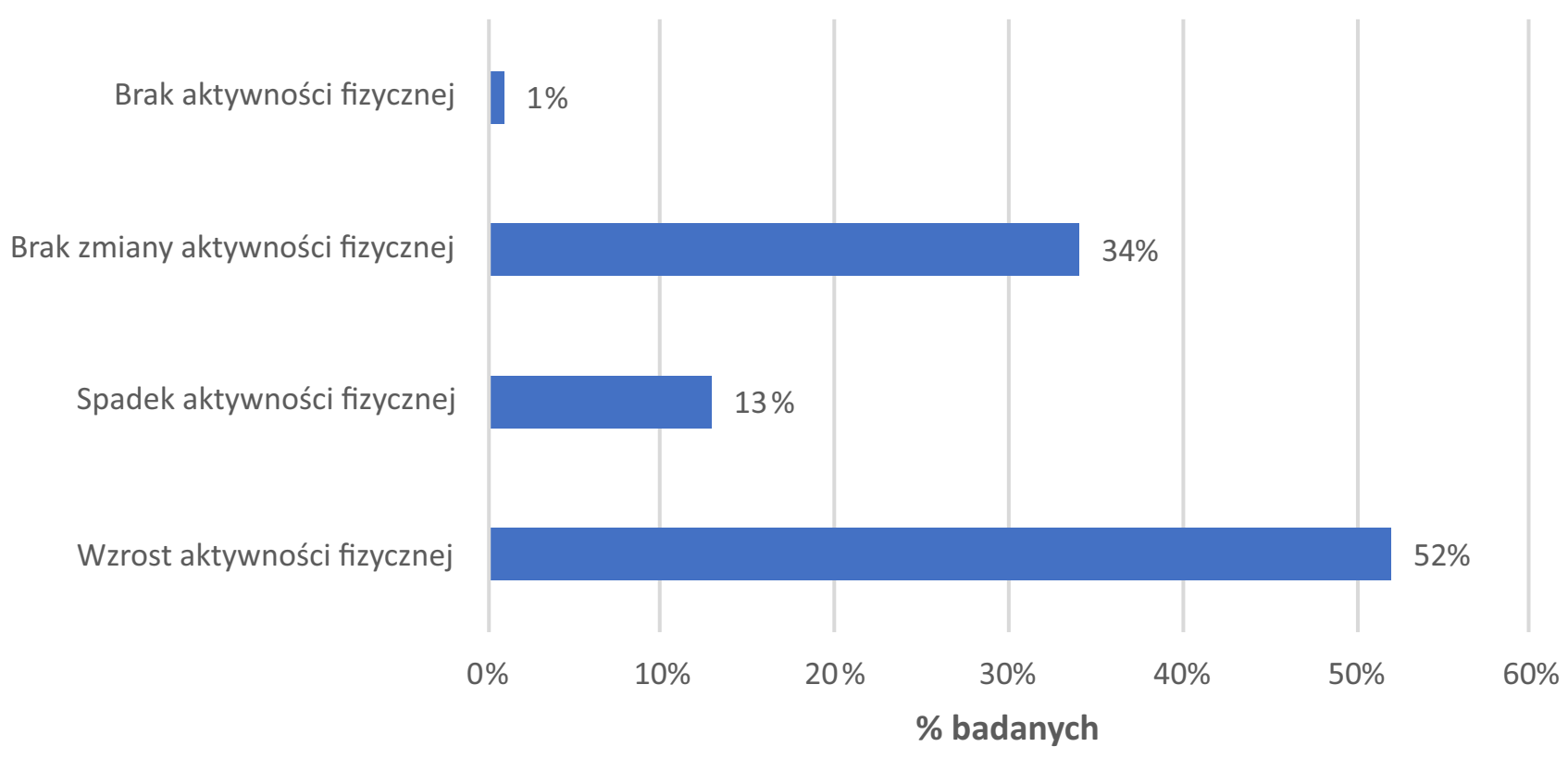

Ryc. 11. Aktywność fizyczna po przejściu na pracę zdalną [źródło: opracowanie własne] 


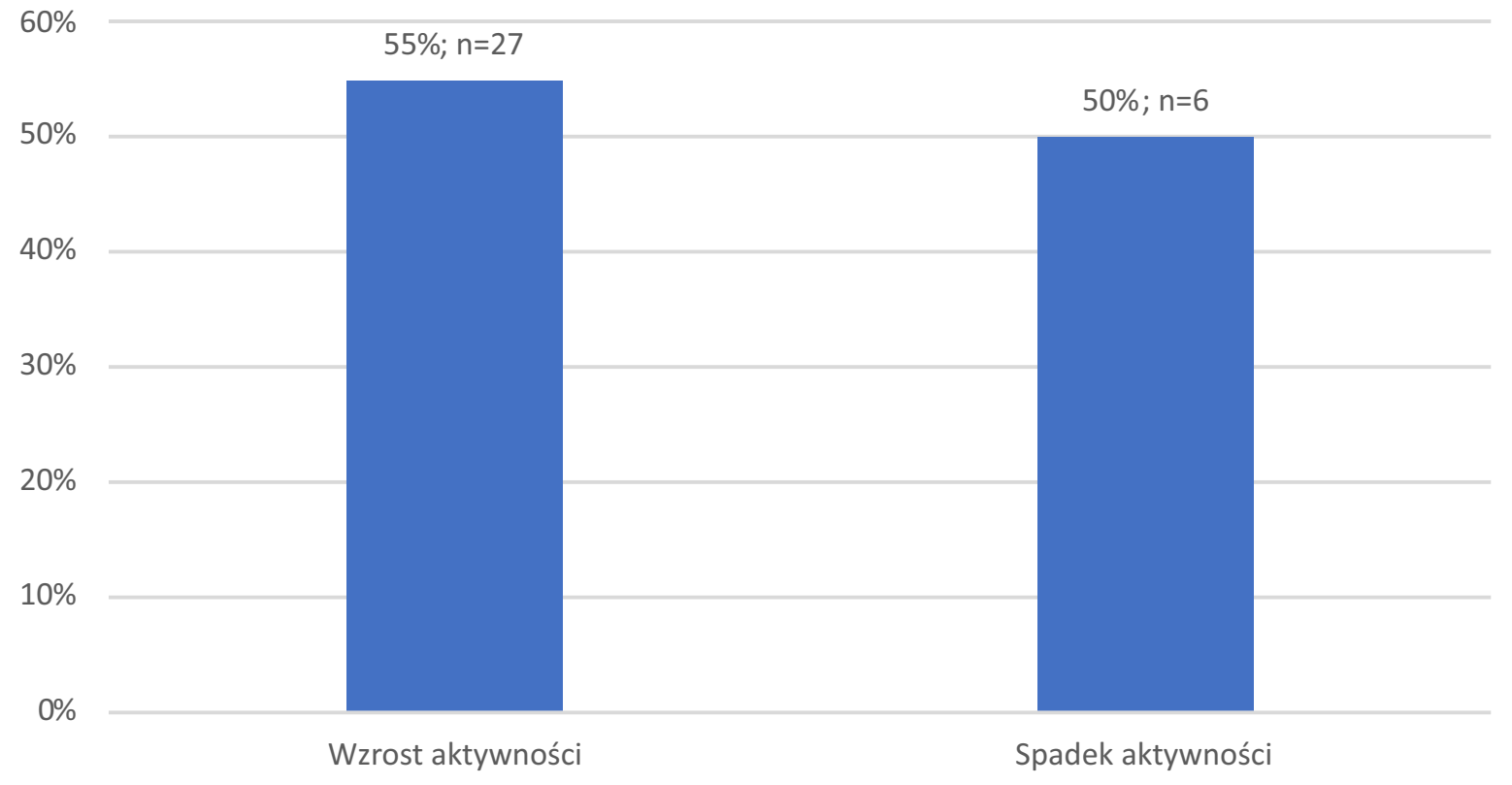

Ryc. 12. Wpływ zmiany aktywności na częstość występowania dolegliwości szyjnych [źródło: opracowanie własne]

ergonomii miejsca pracy. Wskaźnik ten jest wartością średnią poziomu ergonomii miejsca pracy ocenianej przez pracownika dla 5 parametrów ocenianych na skali 1-5, gdzie 1 to "bardzo niewygodne”, a 5 to „bardzo wygodne”: krzesło, biurko, monitor, klawiatura i mysz oraz oświetlenie. W celu zobrazowania zależności pomiędzy ergonomia miejsca pracy a częstością występowania dolegliwości, posłużono się medianą wartości wskaźnika ergonomii. Obliczono częstość wystąpienia dolegliwości szyjnych poniżej i powyżej wartości mediany wskaźnika ergonomii dla pracy biurowej oraz pracy zdalnej. Wyciągnięto średnie wartości oraz obliczono odchylenie standardowe dla takich parametrów, jak: wiek badanych, wartość wskaźnika NDI oraz wskaźniki ergonomii miejsca pracy.

\section{Wyniki}

Ankietę uzupełniło 103 pracowników biurowych (55 kobiet i 48 mężczyzn) w wieku od 24 do 52 lat (Średnia wieku: $30,5 ; \mathrm{SD}: 4,45)$.
Spośród 62 osób zgłaszających dolegliwości w pracy biurowej, 17 osób (27\%) nie zaznaczyło występowania dolegliwości bólowych po przejściu na „home office”. Dla tych pracowników, u których dolegliwości występowały nadal, sprawdzono zmianę wskaźnika NDI. Średnia wartość NDI dla pracujących w biurze wynosiła 18,5 punktu (SD: 4,87) i spadła po przejściu na pracę zdalną do 16,38 punktu (SD: 2,77 ), zmiana o średnio $11,5 \%$.

W pierwszej połowie ankiety 41 osób zaznaczyło brak odczuwanych dole-gliwości ze strony szyi. $Z$ tej grupy 10 respondentów (25\%) zaznaczyło pojawienie się dolegliwości po przejściu na pracę zdalną. Wartość średnia wskaźnika NDI dla osób, u których pojawiły się dolegliwości szyjne, wyniosła 17 punktów (SD: 2,45).

Średnia wartość wskaźnika ergonomii miejsca pracy dla biura wyniosła 3,72 (SD: 0,51). Praca zdalna była realizowana w warunkach o średnim wskaźniku ergonomii 3,17 (SD: 0,66). Dla pracy biurowej mediana wskaźnika ergonomii przypadła na 3,8 punktu, dzieląc respondentów na grupy o liczebności osób 49 i 54. W pracy zdalnej mediana wskaźnika postrzeganej ergonomii przypadła na 3,2 punktu, dokonujac podziału ankietowanych na dwie grupy o liczebności 53 i 50 osób (ryc. 7).

Aktywność fizyczną dotyczącą okresu pracy biurowej sklasyfikowano w 4 przedziałach: brak aktywności fizycznej, aktywność fizyczna poniżej 2,5h w tygodniu, aktywność fizyczna między 2,5 i 5h w tygodniu, aktywność fizyczna powyżej 5h tygodniowo. W drugiej części ankiety zaznaczano, czy i w jaki sposób aktywność fizyczna zmieniła się po przejściu na pracę zdalną. Rycina 10 przedstawia częstotliwość występowania dolegliwości szyjnych w zależności od poziomu aktywności fizycznej.

Sprawdzono częstość występowania objawów szyjnych po przejściu na prace zdalną w poszczególnych grupach respondentów w zależności od wskazanej zmiany aktywności fizycznej. Zależności te prezentuje ryc. 12 . 


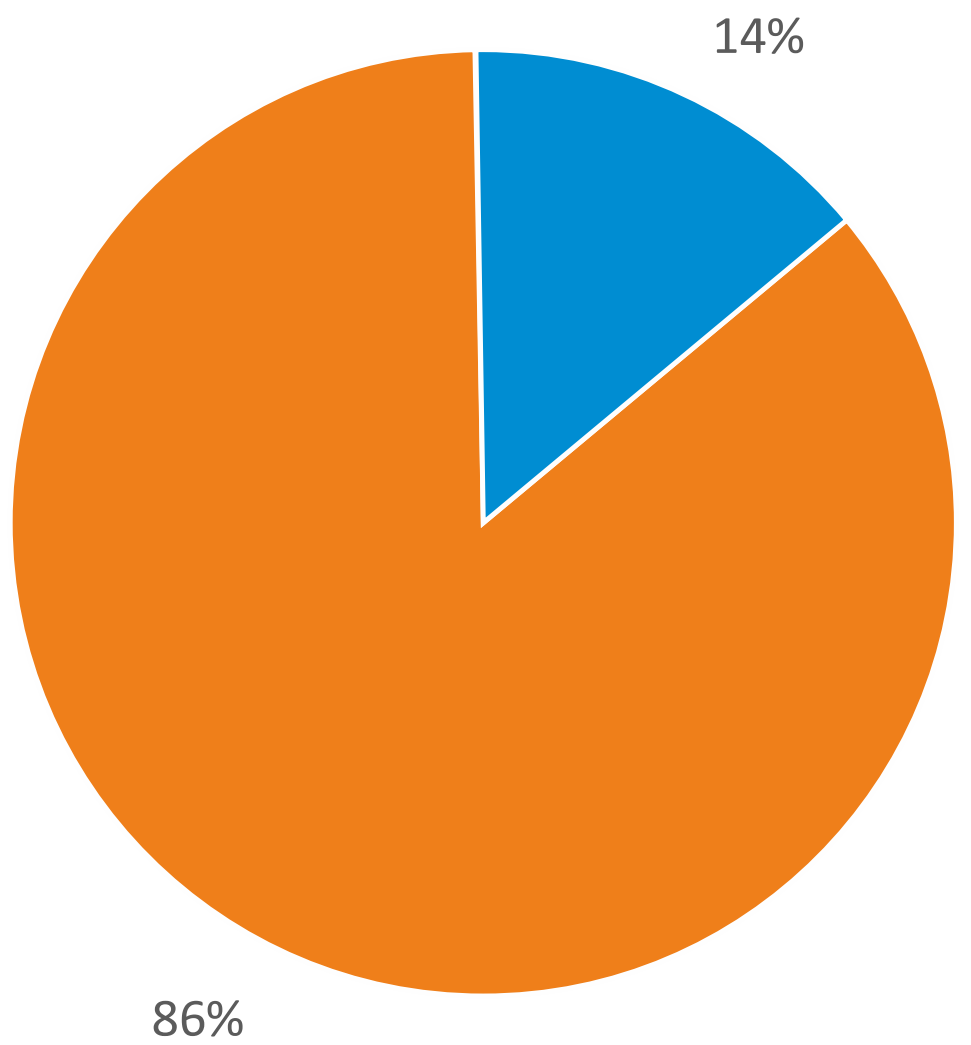

- Tak nie

\section{Ryc. 13. Uraz szyi w przeszłości [źródło: opracowanie własne]}

Badania umożliwiły zebranie danych dotyczących przebycia urazu odcinka szyjnego kręgosłupa. Taki uraz wystąpił w przeszłości u $14 \%$ ankietowanych (ryc. 13).

W grupie osób z urazem szyi w historii, częstość występowania dolegliwości kręgosłupa szyjnego znacząco przewyższała tą obserwowaną w grupie osób, które nie wskazały takiego urazu w przeszłości (ryc. 14 i 15).

\section{Dyskusja}

Pomimo stwierdzenia dużej zmienności czasu spędzanego w pozycji siedzącej przez ankietowanych pracowników biurowych, nie wykazano związku pomiędzy liczbą godzin spędzona w pozycji siedzacej w ciągu doby, a nasileniem dolegliwości szyjnych ani w pracy w biurze ani w pracy zdalnej. Analiza wyników wykazała częstsze występowanie dolegliwości szyjnych podczas pracy zdalnej w porównaniu do pracy biurowej u kobiet $(70 \%$ kobiet w trakcie pracy biurowej i 55\% kobiet w trakcie pracy zdalnej) niż u mężczyzn ( $56 \%$ w biurze i $52 \%$ w domu). Płeć żeńska wiąże się z większą częstotliwością występowania dolegliwości szyjnych, podobnie jak wykazali to inni badacze m.in. Fejer [3] i Paksaichol [14].

Wśród ankietowanych osób nie znaleziono zależności między ilością czasu spędzaną w pracy w pozycji siedzącej a dolegliwościami odcinka szyjnego kręgosłupa. Według Johnston i wsp. [15], spedzanie przed komputerem $6 \mathrm{~h}$ wystarcza, by razem z niekorzystnymi czynnikami psychosocjalnymi, takimi jak niezadowolenie z wykonywanej pracy czy negatywne nastawienie do realizowanych obowiązków, wywołać objawy niepełnosprawności szyjnej. W niniejszym opracowaniu grupy o skrajnie niskiej i skrajnie wysokiej objętości pracy siedzącej są stosunkowo nieliczne. W kontekście niektórych opracowań jak np. Hallman i wsp. [16], opisujących mniejszą częstość występowania dolegliwości szyjnych u osób pracujących dłużej w pozycji siedzącej, należy zbadać dokładniej osoby spędzające przy komputerze niewiele i skrajnie dużo czasu.

Dolegliwości odcinka szyjnego kregostupa a tryb pracy (biurowa i zdalna)

W badaniach własnych wśród 103 
badanych $60 \%$ zgłaszało dolegliwości szyjne w trakcie pracy stacjonarnej biurowej. Praca zdalna wiązała sie z wystąpieniem dolegliwości szyjnych u 55 osób (53\%). Zaobserwowano zmniejszenie się liczby badanych z dolegliwościami szyjnymi po przejściu na zdalny tryb pracy. $\mathrm{W}$ trakcie realizowania pracy zdalnie o 11\% mniej osób odczuwało dolegliwości szyjne. Dla osób, które odczuwały dolegliwości w trakcie pracy biurowej, średnia wartość wskaźnika NDI wyniosła 18,5 punktów (SD: 4,87). Pracownicy, którzy zgłaszali dolegliwości w trakcie realizowania obowiązków zdalnie, odczuwali dolegliwości średnio na poziomie 16,5 punktów (SD: 3,99). Można zatem wywnioskować, że jednocześnie ze zmniejszeniem się występowania dolegliwości po przejściu na prace zdalną, stopień ich nasilenia także zmniejszył się. Tavares [17] stwierdził podobnie, że praca zdalna może mieć dobry wpływ na ogólne zdrowie pracownika.
Wptyw przejścia na tryb pracy zdalnej na zmiane odczuwanych dolegliwości szyjnych.

Spośród 62 osób zgłaszających dolegliwości w pracy biurowej, 27\% nie zaznaczyło występowania dolegliwości bólowych w trakcie telepracy, zatem częstość występowania dolegliwości zmniejszyła się. Dla tych pracowników, u których dolegliwości występowały nadal, po przejściu na "home office” zaobserwowano poprawe stanu zdrowia (średnia wartość NDI spadła o średnio $11,5 \%)$. W pierwszej połowie ankiety 41 osób zaznaczyło brak odczuwanych dolegliwości ze strony szyi. Z tej grupy $25 \%$ osób zaznaczyło pojawienie się dolegliwości po przejściu na pracę zdalną. Wiadomym jest, że czynniki psychiczne i społeczne odgrywają istotną rolę w powstawaniu i utrzymywaniu się bólu szyi [18]. Jednoznaczne stwierdzenie czy przejście na telepracę wiąże się z poprawą stanu zdrowia w ujęciu odcinka szyjnego kręgosłupa wymaga głębszego prze- analizowania czynników psychospołecznych występujących w obydwu środowiskach i wnikliwego ich porównania.

Ergonomia miejsca pracy a częstotliwość występowania dolegliwości szyjnych

Ergonomia miejsca wykonywania pracy zdalnej była w ocenie pracowników gorsza od ergonomii biura, w którym wcześniej wykonywali obowiązki służbowe. Parametr ten wydaje się mieć znaczenie w kontekście zdrowia pracowników [19], ale w przypadku zmiany miejsca pracy $\mathrm{z}$ biura na przestrzeń do pracy zdalnej postrzeganej przez pracownika jako o gorszej ergonomii, zdaje się nie mieć aż tak dużego znaczenia. Pomimo zauważalnego spadku warunków ergonomii miejsca do pracy zdalnej w stosunku do stacjonarnej przestrzeni biurowej, doszło jednak do zauważalnej poprawy odczuwanych dolegliwości po rozpoczęciu pracy w domu. Być może ma to związek $\mathrm{z}$ potencjalnie lepszymi

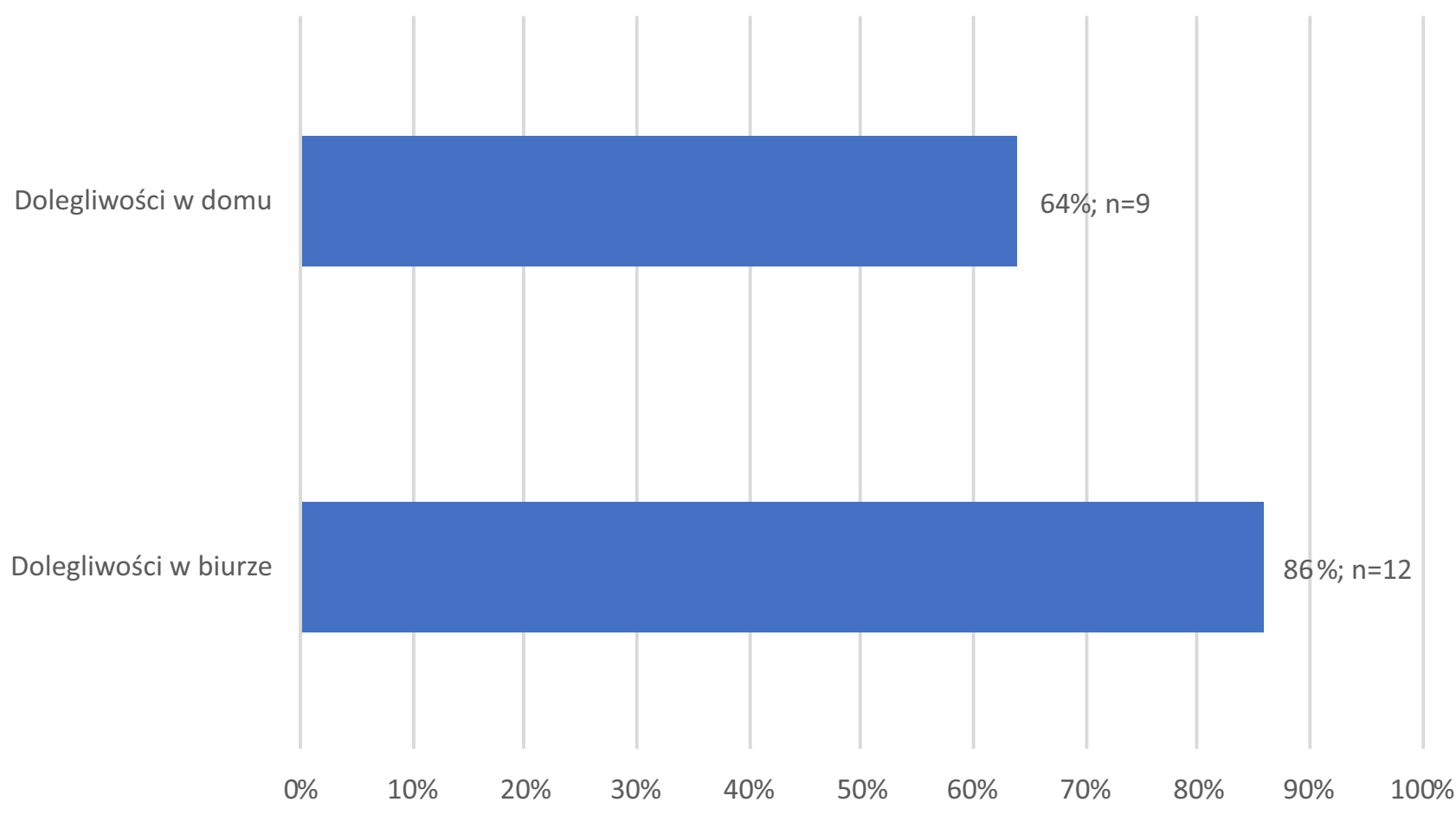

Ryc. 14. Częstość występowania dolegliwości u osób po urazie [źródło: opracowanie własne] 


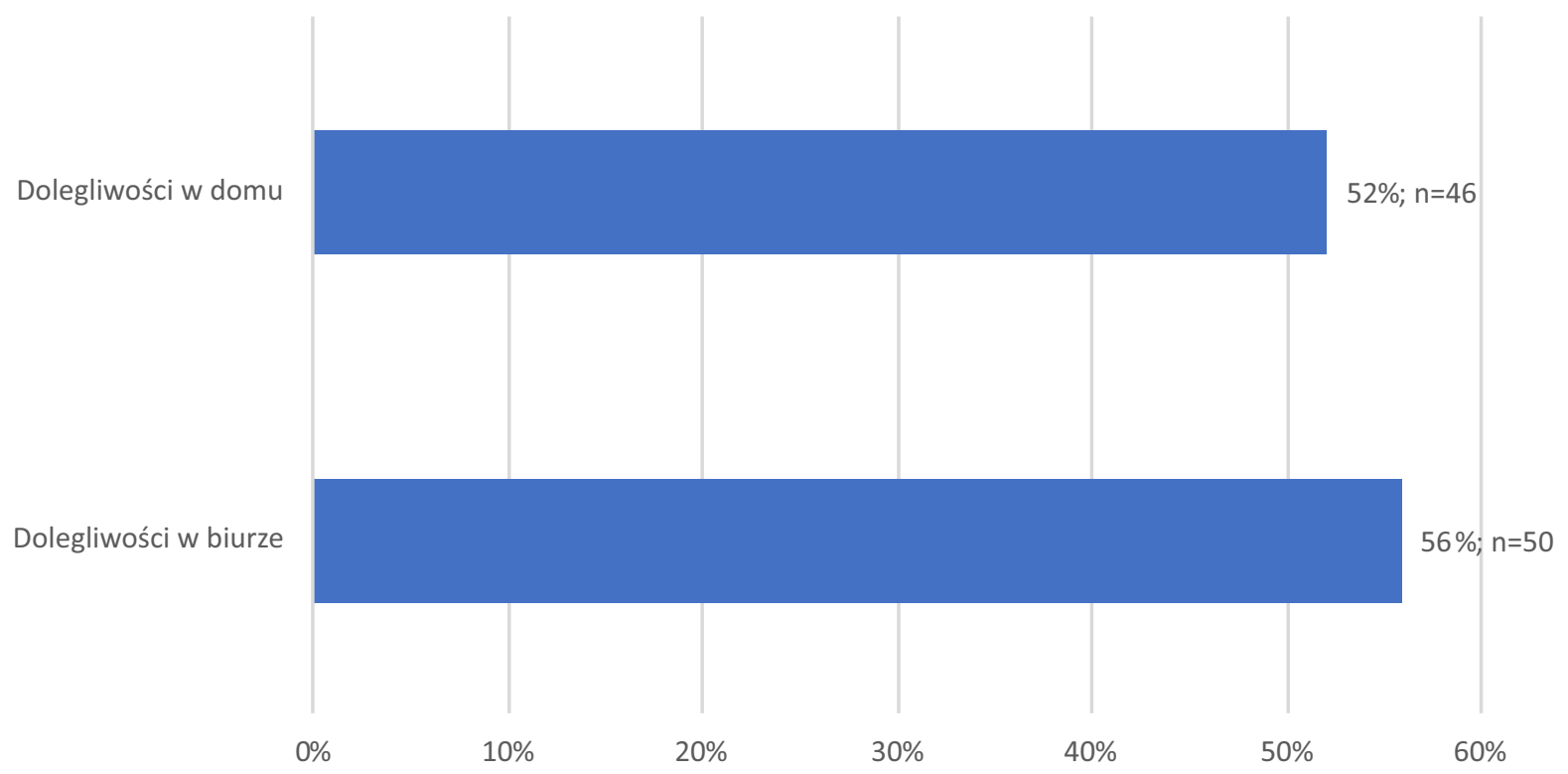

Ryc. 15. Częstość występowania dolegliwości u osób bez urazu szyi [źródło: opracowanie własne]

możliwościami bardziej efektywnego spędzania czasu przerw? U pracowników bez wydzielonej przestrzeni do odpoczynku w biurze, częstość występowania dolegliwości szyjnych była zauważalnie wyższa niż u osób, które mogły w pracy odpocząc w specjalnie wydzielonym do tego celu miejscu. Istnieje prawdopodobieństwo, że dla tych pracowników, którzy nie odczuwali dolegliwości przed przejściem do „home office”, deficyt ergonomiczny miejsca pracy zdalnej okazał się wystarczający, żeby sprowokować pojawienie się dolegliwości.

\section{Dolegliwości szyjne w kontekście zmian $w$} aktywności fizycznej badanych

Poziom aktywności fizycznej respondentów wpływał na występowanie dolegliwości szyjnych. Procentowa reprezentacja pracowników odczuwających dolegliwości szyjne malała wraz ze wzrostem objętości podejmowanej aktywności fizycznej. Zaobserwowana zależność nie jest odosobnionym zjawiskiem. Pozytywny wpływ aktywności fizycznej na zdrowie wykorzystuje się także w programowaniu terapii w różnego rodzaju dolegliwościach i bólach szyi w tym także z poważniejszymi objawami np. korzeniowymi [20].

Po przejściu na tryb zdalny, u $13 \%$ ankietowanych doszło do spadku aktywności fizycznej, ale aż u 52\% poziom aktywności fizycznej wzrósł, a u pozostałych ankietowanych poziom nie zmienił się. Analizując wpływ zmiany stopnia aktywności fizycznej po przejściu na pracę zdalną ciężko jednoznacznie określić, czy zmiana w objętości aktywności wpływa na częstość występowania objawów ze strony szyi. W jednej i w drugiej grupie częstość występowania jest zbliżona (50\% i 55\%), ponadto grupa, w której aktywność ruchowa spadła jest kilkukrotnie mniejsza od grupy, w której doszło do zwiększenia objętości podejmowanej aktywności fizycznej po przejściu na pracę zdalną.

Uraz szyi występujacy $w$ przesztości a dolegliwości bólowe odcinka szyjnego kregostupa

Na podstawie uzyskanych wyników wydaje się, że osoby po urazie szyi charakteryzowały się znacznie większą częstością występowania dolegliwości bólowych podczas pracy biurowej $(86 \%$ $\mathrm{n}=12$ ) niż pracownicy bez takiego urazu w historii $(56 \%, \mathrm{n}=50)$. Można stwierdzić jedynie występowanie pewnych tendencji w tym zakresie, ponieważ reprezentacja osób po urazie szyi w badaniach własnych stanowiła niewielki odsetek wszystkich ankietowanych (14\%). Jednak obserwacje te są zbieżne z wynikami badań innych autorów, m.in.. Paksaichol [14], Croft [21], czy Huysmans [22], wg których uraz odcinka szyjnego jest czynnikiem ryzyka wystąpienia dolegliwości bólowych szyi w późniejszym okresie.

\section{Wnioski}

1. Praca $w$ formie zdalnej nie musi nieść ze sobą ryzyka wystąpienia dolegliwości bólowych odcinka szyjnego kręgosłupa.

2. W trakcie pracy zdalnej mniej pracowników zgłaszało dolegliwości 
szyjne oraz były one mniej nasilone niż w trakcie pracy w biurze.

3. Ergonomia miejsca pracy ma wpływ na występowanie dolegliwości. Im gorsza ergonomia miejsca pracy, tym częściej występują dolegliwości zarówno w pracy stacjonarnej w biurze, jak i w pracy zdalnej.

4. Zmiana trybu pracy wiąże się ze zmiana tygodniowej objętości aktywności fizycznej w stronę zwiększenia ilości podejmowanego wysiłku, ale nie wykazano tu związku z częstością występowania dolegliwości odcinka szyjnego kręgosłupa.

5. Pracownicy, którzy podejmowali systematyczną i intensywną aktywność ruchową znacznie rzadziej zgłaszali dolegliwości bólowe szyi w porównaniu do osób nie podejmujących się aktywności fizycznej.

6. Uraz szyi w przeszłości może powodować większą częstość wystąpienia dolegliwości szyjnych w pracy biurowej.

\section{Piśmiennictwo}

1. Walocha J. Anatomia prawidłowa człowieka. Osteologia. Podręcznik dla studentów i lekarzy. Wydawnictwo UJ, Kraków 2013.

2. Wang H., Naghavi M., Allen C. i wsp. Global, regional, and national life expectancy, allcause mortality, and cause-specific mortality for 249 causes of death, 1980-2015: a systematic analysis for the Global Burden of Disease Study 2015. Lancet. 2016, Vol. 388(10053), pp. 1459-1544.

3. Fejer R., Kyvik K.O., Hartvigsen J. The prevalence of neck pain in the world population: a systematic critical review of the literature. European spine journal. 2006, Vol. 15, pp. 834-48.

4. Childs J.D., Cleland J.A., Elliott J.M. i wsp. Neck Pain: Clinical Practice Guidelines
Linked to the International Classification of Functioning, Disability, and Health From the Orthopaedic Section of the American Physical Therapy Association. J Orthop Sports Phys Ther 2008;38(9): A1-A34. doi:10.2519/jospt.2008.0303.

5. Belzunegui-Eraso A., Erro-Garcés A. Teleworking in the Context of the Covid19 Crisis. Sustainability 2020,12(9), 3662. doi:10.3390/su12093662

6. Peters J. Amazon, Google, Facebook, and Microsoft are asking Seattle-based staff to work from home because of coronavirus. Źródło: https://www. theverge.com/2020/3/5/21166686/coro navirus-amazon-google-facebook microsoft-twitter-seattle-staff-remotework (dostęp: 10/09/2020).

7. Leśniak G. Praca zdalna - rozwiązanie stałe czy przejściowe? [On-line] 25/05/2020. [Cytowany :10/09/2020] https://www.prawo.pl/kadry/pracazdalna-czy-przepisy-przeminawraz-zepidemia-czy-zostana-w,500517.html.

8. Kamińska A. Ponad $5 \mathrm{mln}$ Polaków to pracownicy biurowi - czy pracują w zdrowych warunkach? prasa.velux.pl. [0nLine] 09/05/2019. [Cytowanie: 10/09/2020.] https://prasa.velux.pl/zdrowe-biuro/.

9. Brynjolfsson E., Horton J., Ozimek A., i wsp. COVID-19 and Remote Work: An Early Look at US Data. The National Bureau of Economic Research. [on-line] 06/04/2020. https://www.nber.org/ papers/w27344.

10. Zoellner M. $89 \%$ firm IT przeszło na pracę zdalną [BADANIA]. Kodilla.com. [on-line] 06/07/2020; https://kodilla .com/pl/blog/oferty-pracy-zdalnejdla programisty (dostęp: 10/09/2020).

11. Zoellner M. Praca zdalna w czasach pandemii. Programiści zostali w domach (WYNIKI BADAŃ). Kodilla.com. [online] 06/07/2020 https://kodilla.com/ $\mathrm{pl} / \mathrm{blog} / \mathrm{praca}-z d a l n a-w-c z a s a c h-$ pandemii (dostęp:10/09/2020).
12. Fung B. Twitter will let some employees work from home 'forever'. edition.cnn.com. [online] 12/05/2020 https://edition.cnn.com/2020/05/12/tec h/twitterwork-from-home-forever/ index.html. (dostęp:10/09/2020).

13. Chini M. $84 \%$ wants to keep teleworking after coronavirus crisis. brusselstimes. com. [on-line] 14/05/ 2020, https:// www.brusselstimes.com/news/belgium all- news/111569/ 84-wants-to-keepteleworking-after-coronavirus-crisis/ (dostęp:10/09/2020).

14. Paksaichol A., Janwantanakul P., Purepong N., Pensri P., van der Beek AJ. Office workers' risk factors for the development of non-specific neck pain: a systematic review of prospective cohort studies. Occup Environ Med. 2012;69 (9):610-618. doi:10.1136/ oemed-2011100459

15. Johnston V., Souvlis T., Jimmieson N.L., Jull G. Associations between individual and workplace risk factors for selfreported neck pain and disability among female office workers. Appl Ergon. 2008;39(2):171-182. doi:10.1016/ j.apergo.2007.05.011

16. Hallman D.M., Gupta N., Heiden M. et al. Is prolonged sitting at work associated with the time course of neck-shoulder pain? A prospective study in Danish blue-collar workers. BMJ Open. 2016;6(11):e012689. Published 2016 Nov 10. doi:10.1136/bmjopen-2016012689

17. Tavares A.I. Telework and health effects reviewed. International J of Healthcare. 2017,3(2).

18. Johnston V., Jull G., Souvlis T., Jimmieson N.L. Interactive effects from self-reported physical and psychosocial factors in the workplace on neck pain and disability in female office workers. Ergonomics 2010;53(4):502-513. doi:10.1080/00140130903490692 
19. Mehrparvar A.H., Heydari M., Mirmohammadi S.J., Mostaghaci M., Davari M.H., Taheri M. Ergonomic intervention, workplace exercises and musculoskeletal complaints: a comparative study. Med J Islam Repub Iran. 2014;28:69.

20. Dedering Ĺ., Peolsson A., Cleland J.A., Halvorsen M., Svensson M.A., Kierkegaard M. The Effects of Neck-
Specific Training Versus Prescribed Physical Activity on Pain and Disability in Patients With Cervical Radiculopathy: A Randomized Controlled Trial. Arch Phys Med Rehabil. 2018;99(12):24472456. doi:10.1016/j.apmr.2018.06.008

21. Croft P.R., Lewis M., Papageorgiou A.C. i wsp. Risk factors for neck pain: a longitudinal study in the general population. Pain. 2001;93(3):317-325. doi:10.1016/s0304-3959(01)00334-7.

22. Huysmans M.A., ljmker S., Blatter B.M. i wsp. The relative contribution of work exposure, leisure time exposure, and individual characteristics in the onset of arm-wrist-hand and neckshoulder symptoms among office workers. Int Arch Occup Environ Health. 2012;85(6) :651-666. doi:10.1007/s00420-0110717-5.

www.kif.info.pl 